FOLIA

Amazónico

Revista del Instituto de Investigaciones

de la Amazonía Peruana

\title{
VERTICAL SEGREGATION IN PRISTIMANTIS SPECIES FROM A BAMBOO FOREST IN SOUTHEAST OF AMAZONIA, BRAZIL
}

Jhon Jairo LÓPEZ-ROJAS ${ }^{1}$

1 Universidad Nacional de San Martín, Facultad de Ecología. lopezrojasjj@gmail.com

\begin{abstract}
In this work, the vertical stratification in Pristimantis species was studied in a remanescent forest dominated by bamboo in the southwest region of the Amazon. The field work was carried out between December 2012 and May 2013. The differences in height of the perch were analyzed interspecifically, and intraspecific in relation to the structure of the vegetation. A total of four species were recorded, Pristimantis fenestratus being the most abundant and occurring in all sampling units. There was significant interspecific difference in perch height, as well as between adults and juveniles. For $P$. fenestratus, there was no differentiation of segregation between sampling units. The structure of the vegetation did not explain the preference of heights; however, leaf litter depth influenced its vertical stratification. More data and occurrences are needed in all sampling units to infer better explanations.
\end{abstract}

KEYWORDS: Vertical segregation, Pristimantis, bamboo forest, structure of the vegetation.

\section{DISTRIBUCIÓN VERTICAL EN ESPECIES DE PRISTIMANTIS EN UN BOSQUE DOMINADO POR BAMBÚ EN LA REGIÓN SUROESTE DE LA AMAZONÍA, BRASIL}

\section{RESUMEN}

En este trabajo, se estudió la distribución vertical en especies de Pristimantis en un bosque dominado por bambú en la región suroeste de la Amazonía. Los muestreos se realizaron entre diciembre del 2012 y mayo del 2013. Las 
diferencias de la altura de percha fueron analizadas inter e intra-especificamente en relación a la estructura de la vegetación. Un total de cuatro especies fueron registradas, Pristimantis fenestratus fue la más abundante ocurriendo en total las unidades de muestreo. Hubo una diferencia significativa en la altura de percha, tanto en adulto como en juveniles. Para P. fenestratus no hubo diferencia de segregación entre las unidades de muestreo. La estructura de vegetación no explicó la preferencia vertical, sin embargo, la profundidad de la hojarasca explicó su estratificación. Mas datos y ocurrencias son necesarios en todas las unidades para inferir mejores explicaciones.

PALABRAS CLAVES: Segregación vertical, Pristimantis, bosque dominado por bambú, estructura de la vegetación. 


\section{INTRODUCTION}

Niche theory suggests that coexisting species will reduce the effects of interspecific competition through the segregation of shared resources (Chesson, 2000), these coexisting species often use different tactics without causing a competitive exclusion of resources occupying different habitats (Caramashi, 1981; Hauer and Stanford, 1986; Kiszka et al., 2011).

Several studies have focused vertical stratification in Anura (Arroyo et al., 2008; Muñoz-Guerrero, 2007; Guayasamin and Funk, 2009; de Menezes Gondim, 2013; FonsecaPérez, 2017). To explain this behavioral and ecological activity, different strategies are used by the anuran species to coexist in the same habitat: ontogenetically (Eterovick et al., 2010, de Menezes Gondim, 2013), foraging sites and competition inter and intraspecific (Duellman and Pyles, 1983; Toft, 1985), and by attracting females during the breeding season by strategic vocalization frequencies in males (Miyamoto, 1982). However, until now there have been no approaches that relate vertical intra-specific segregation (de Menezes Gondim, 2013) and interspecific segregation with variables that structure the vegetation.

The focus on anuran species of the genus Pristimantis Jiménez de la Espada, 1870, has involved particularities in their natural history of direct development (Pombal and Haddad, 2007), as sensitive indicators of anthropogenic disturbances (Pearman, 1997), and present vertical stratifications in vegetation (Lynch and Duellman, 1997; Guayasamin and Funk, 2009; Blair and Doan, 2009). This genus is one of the most diverse groups of amphibians in the Neotropics, with 38 species occurring in Brazil (Segalla et al., 2017). The southwestern region of the Brazilian Amazon is characterized by the presence of patches of bamboo (Silveira, 2005).
The dynamics of bamboo growth is crucial in influencing vegetation structure in richness and abundance in this assemblage, differentiating certain habitats of targeted species (López-Rojas et al., 2015).

In this study the vertical distribution of species of the genus Pristimantis occurring in syntopy in a fragmented forest dominated by bamboo, needs to address questions regarding vertical stratification and interspecific differences between adults and juveniles. Additionally, does the vegetation structure influence the vertical segregation of the various species?

\section{MATERIAL AND METHODS}

The work was carried out in a forest fragment known as Fazenda Experimental Catuaba $\left(10^{\circ} 04^{\prime} \mathrm{S}, 67^{\circ} 37^{\prime} \mathrm{W}\right)$, in the municipality of Senador Guiomard, Acre State, Brazil. It comprises an area of 1200 ha, dominated by bamboo, Guadua weberbaueri Pilger (Smith and Nelson, 2011). Distribution of plots in Catuaba, measurements and analysis of vegetation structure variables are detailed in López-Rojas et al. (2015). Field work was conducted for a total of 70 days of sampling, largely during the rainy season, between November 2012 and May 2013, with twice monthly visits, each five days in length, totaling 180 hours of observations, with an average of 12 repetitions for each plot.

The sampling of Pristimantis was carried out at night using active visual and auditory survey (Crump and Scott 1994). Two researchers surveyed each plot for approximately 90 minutes, searching the trail to an extent of two meters wide on both sides of the central line, up to a height of three meters between 17:00 $\mathrm{h}-$ 23:00 $\mathrm{h}$. For each individual frog observed, I recorded the perching height above ground level using metric measurements. Snout-vent-length (SVL) was 
measured with a digital caliper to differentiate adults from juveniles, under the criteria of Lehr and Duellman and Lehr (2009), Padial de la Riva (2009). All specimens encountered were identified in the field or in the laboratory, by comparison with specimens deposited in the Herpetological Collection of the Universidade Federal do Acre.

After analysis of homoscedasticity and normality of the data, an analysis of variance (ANOVA) wasperformed to identify the differences in the use of the perching height among the species. The significance of the differences between pairs of means was calculated by the Tukey-Kramer method. The intraspecific difference between adults and juveniles was done through a T-test.
P. fenestratus was present in all plots, so it was possible to infer if there was an intraspecific difference in all the sampling units by ANOVA. Likewise, the vegetation structure variables and the first axis of the PCA (see, López-Rojas et al., 2015) were used to relate them to the mean height in each plot by linear regression. All analyzes were performed in RStudio 1.0.153 (R, 2015) and Statistic 10 (StatSoft Inc., 2011).

\section{RESULTS}

Perching height above ground level was recorded in 229 individuals of four species of Pristimantis. There was interspecific difference in relation to

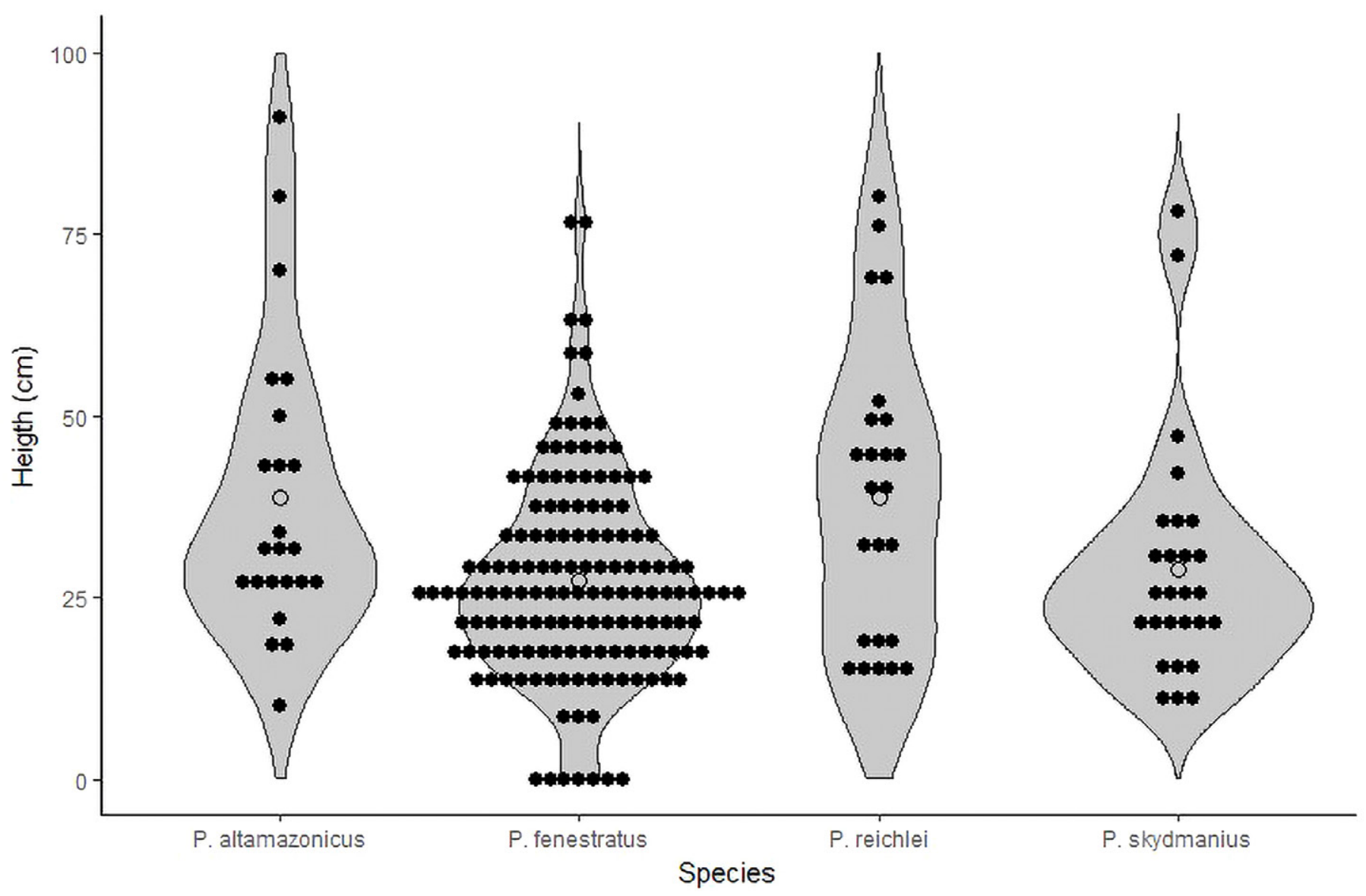

Fig 1. Vertical distribution of four species of Pristimantis in Catuaba, Acre, Brazil. 
Table 1. Descriptive data and ontogenetic differences in four species of Pristimantis observed in Catuaba, Acre State, Brazil. N=Number of individuals; $\mathrm{M}=$ Mean; $\mathrm{SD}=$ Standard Deviation; $\mathrm{t}=$ Student $\mathrm{t}$-test; $\mathrm{p}=$ Propability.

\begin{tabular}{|c|c|c|c|c|c|}
\hline Species & $\mathrm{N}$ & M & SD & $t$ & $p$ \\
\hline \multicolumn{6}{|c|}{ P. altamazonicus } \\
\hline Adults & 16 & 35.8 & 18.2 & -2.76 & $<0.01$ \\
\hline Juveniles & 10 & 69.5 & 43.1 & & \\
\hline \multicolumn{6}{|l|}{$P$. fenestratus } \\
\hline Adults & 56 & 22.3 & 10.0 & -3.29 & 0.00 \\
\hline Juveniles & 91 & 34.2 & 25.8 & & \\
\hline \multicolumn{6}{|l|}{ P. reichlei } \\
\hline Adults & 15 & 32.0 & 23.7 & -2.88 & $<0.16$ \\
\hline Juveniles & 13 & 65.8 & 35.9 & & \\
\hline \multicolumn{6}{|c|}{ P. skydmainus } \\
\hline Adults & 12 & 23.8 & 7.1 & -2.3 & $<0.01$ \\
\hline Juveniles & 16 & 43.0 & 32.6 & & \\
\hline
\end{tabular}

the hanger height (ANOVA, $\mathrm{F}_{3,225}=8.02, p<0.01$, Fig 1). P. altamazonicus, $P$. fenestratus and $P$. skydmainus occupied ranges of heights between 20 and $39 \mathrm{~cm}$, whereas $P$. reichlei was more common between 40 and $59 \mathrm{~cm}$ (Fig. 1).

Perching height in $P$. fenestratus was significantly lower than $P$. altamazonicus and $P$. reichlei (Tukey-Kramer method, $p=0.04 \mathrm{y}$ $p=0.02$ ), but did not differ from $P$. skydmainus (Tukey-Kramer method, $p>0.05$ ). P. reichlei and $P$. skydmanus also showed differences in perch height (Tukey-Kramer method, $p=0.04$ ).

In the case of $P$. fenestratus, there was no significant difference of the hanger height distributed in the sampling units (ANOVA, $\left.\mathrm{F}_{9,199}=0.83, p>0.59\right)$. The structure of the vegetation did not influence its vertical distribution $\left(\mathrm{R}^{2}=0.27, p=0.13\right)$. Only leaf litter depth explained $51 \%$ of distribution $\left(\mathrm{R}^{2}=0,51\right.$, $p=0.02$ ).

\section{DISCUSSION}

This study showed a more quantitative subject regarding Lynch and Duellman (1997), and itwaspossibletofindintraspecific differences in relation to the height of the substrate used for these nocturnally active frogs. Pristimantis exhibit a greater detectability in the rainy season (Arroyo et al., 2008; Waldez et al., 2011), and the present work was carried out during the majority of this fivemonth period, in contrast to the work of Miyamoto (1982) and Guayasamin and Funk (2009) which took two months and two years respectively.

Other authors have observed the vertical distribution of micro-habitats among Pristimantis species in other regions: western Ecuador (Guayasamani and Funk, 2009; Lynch and Duellman, 1997) and Costa Rica (Miyamoto, 1982). Here I show vertical segregation in the southwest region of the Amazon in a forest dominated by bamboo. This type of vegetation presents effects of the dynamics imposed by bamboo, affecting the structure of vegetation (Griscom and Ashton, 2003; Silveira, 2005; Griscom et al., 2007) and being able to influence vertical segregation for active anuran species. The complexity of the structure of vegetation of this type of forest accounts for some species of Pristimantis to be very low.

In López-Rojas et al. (2015), P. altamazonicus was detectable in areas with trees greater than 30 cm diameter at breast height with a closed canopy with abundant litter, while $P$. fenestratus prefers sites with bamboo and trees with a diameter at 
brest height greater than 10. P. skydmainus, one of the species most sensitive to bamboo, was mostly restricted to heights of less than $45 \mathrm{~cm}$, in some cases individuals were observed at heights higher than $200 \mathrm{~cm}$ concordant on the use of assemblage microhabitat of Pristimantis (Arroyo et al., 2008).

There was overlap in the location of the vertical zone among some species, although they differed in terms of abundance, ontogenetically and in habitat distribution. The differentiation between adults and juveniles may be due to the fact that adults position themselves at strategic sites during the night in search of food and sexual partners (Duellman and Pyles, 1983), males position themselves for optimal vocalization sites, while females, that are already gravid, can remain on the ground due to the increase in their body weight to avoid energetic wear (Crump, 1974). Juveniles, however will usually hide in leaf litter to avoid predators (Blair and Doan, 2009).

The height above ground level was analyzed for $P$. fenestratus in relation to environmental variables, since it is the most abundant species in the study area. In some instances, this species was found vocalizing at heights 20 and $39 \mathrm{~cm}$ during nighttime which could be interpreted as a search for sexual partners, or for surpassing the $150 \mathrm{~cm}$ height used to confuse possible predators i.e. bats (Duellman and Pyles, 1983; Blair and Doan, 2009). Females were also observed on the ground presumably in order to deposit their eggs in leaf litter (Crump, 1974).

Although vertical segregation it was related to the structure of the vegetation, it was not possible to explain variation, except that leaf litter was used to provide shelter, food, breeding, and oviposition sites (Slowinski et al., 1987). Because of this, a greater number of observational records of the other species is required, as well as assessment of additional biotic and abiotic factors, that were not taken in this study, for a better understanding of the vertical variation of microsimpatric species (syntopics).

\section{ACKNOWLEDGEMENTS}

Paulo Melo, for reading the manuscript and providing references. This work was supported by post-graduate fellowships from Coordenação de Aperfeiçoamento de Pessoal em Nivel Superior (CAPES) and Programa de Pesquisa em Biodiversidade (PPbio) núcleo Acre to JJLR. Authorization and Biodiversity Information System (SISBIO) for collecting permits (license number 37974-1). Thanks also to Paul Freed for assistance in editing this manuscript.

\section{REFERENCES}

Arroyo, S.B.; Serrano-Cardozo, V.H. ; RamírezPinilla, M.P. 2008. Diet, microhabitat and time of activity in a pristimantis (anura, strabomantidae) assemblage. Phyllomedusa: Journal of Herpetology, 7: 109-119.

Blair, C. , Doan, T.M. 2009. Patterns of community structure and microhabitat usage in peruvian pristimantis (anura: Strabomantidae). Copeia 2: 303-312.

Butlin, R.K. ; Saura, M. ; Charrier, G. ; Jackson, B. ; André, C. ; Caballero, A. ; Coyne, J.A. ; Galindo, J. ; Grahame, J.W. ; Hollander, J. ; Kemppainen, P. ; Martínez-Fernández, M. ; Panova, M. ; Quesada, H. ; Johannesson, K.; Rolán-Alvarez, E. 2014. Parallel evolution of local adaptation and reproductive isolation in the face of gene flow. Evolution, 68: 935-949.

Caramaschi, U. 1981. Variação estacional, distribuição espacial e alimentação de populações de hilídeos na represa do rio Pardo 
(Botucatu, SP) (Amphibia, Anura, Hylidae). Unpublished dissertation, Universidade Estadual de Campinas, Campinas, 139 pp.

Chesson, P. 2000. Mechanisms of maintenance of species diversity. Annual review of Ecology and Systematics, 31: 343-366.

Crump, M.L. 1974. Reproductive Strategies in a Tropical Anuran Cominunity. The University of Kansas Museum of Natural History. Lawrence. de Menezes Gondim, P. ; Borges-Leite, M.J. ; Pinheiro, L. ; Borges-Nojosa, D.V. ; Cascon, P. 2013. Microhabitat use (vertical distribution) by a population of Dendropsophus gr. microcephalus (Anura, Hylidae) in a forested area of coastal tableland of north-eastern Brazil. Herpetology Notes, 6: 363-368.

Duellman, W.E., Lehr, E. 2009. TerrestrialBreeding Frogs (Strabomantidae) in Peru. Germany, Naturund Tier - Verlag GmbH.

Duellman, W.E., Pyles, R.A. 1983. Acoustic resource partitioning in anuran communities. Copeia, 1983(3): 639-649.

Eterovick, P.C. ; Rievers, C.R. ; Kopp, K. ; Wachlevski, M. ; Franco, B.P. ; Dias, C.J. ; Barata, I.M. ; Ferreira, A.D.M. ; Afonso, L.G. 2010. Lack of phylogenetic signal in the variation in anuran microhabitat use in southeastern Brazil. Evolutionary Ecology 24: 1-24.

Fonseca-Pérez, K.A. ; Molina, C. ; Tárano, Z. 2017. Diet of Dendropsophus microcephalus and Scarthyla vigilans (Anura: Hylidae) at a locality in north-western Venezuela with notes on microhabitat occupation. Papéis Avulsos de Zoologia 57(7): 93-104.

Griscom, B.W., Asthton, P.M.S. 2003. Bamboo control offorest succession: Guadua sarcocarpa in southeastern Peru. Forest Ecology Manage, 175:445-454.

Griscom, B.W. ; Daly, D.C. ; Asthton, P.M. 2007: Floristics of bamboo-dominated stands in lowland terra-firma forests of southwestern
Amazonia. The Journal of the Torrey Botanical Society, 134(1):108-125.

Guayasamin, J.M., Funk, W.C. 2009. The amphibian community at yanayacu biological station, ecuador, with a comparison of vertical microhabitat use among pristimantis species and the description of a new species of the pristimantis myersi group. Zootaxa 2220: 4166.

Hauer, F.R. and Stanford, J.A. 1986. Ecology and coexistence of two species of Brachycentrus (Trichoptera) en Rocky Mountain river. Canadian Journal of Zoology, 64: 1469-1474.

Kiszka, J. ; Simon-Bouhet, B. ; Martinez, L. ; Pusineri, C. ; Richard, P. ; Ridoux, V. 2011. Ecological niche segregation within a community of sympatric dolphins around a tropical island. Marine Ecology Progress Series 433: 273-288.

López-Rojas, J.J. ; Souza, M.B. ; Morato, E.F. 2015: Influence of habitat structure on pristimantis species (anura: Craugastoridae) in a bamboodominated forest fragment in southwestern amazonia. Phyllomedusa: Journal of Herpetology 14: 19-31.

Lynch, J.D., Duellman, W.E. 1997: Frogs of the genus Eleutherodactylus Leptodactylidae in western Ecuador: systematics, ecology, and biogeography. University of Kansas, Lawrence, Natural History Museum, 23: 1-236.

Muñoz-Guerrero, J.; Serrano, V.H.; RamírezPinilla, M.P. 2007. Uso de microhábitat, dieta, y tiempo de actividad en cuatro espécies simpátricas de ranas hílidas neotropicales (Anura: Hylidae). Caldasia 29(2): 413-425.

Miyamoto, M.M. 1982. Vertical habitat use by Eleutherodactylus frogs (Leptodactylidae) at two Costa Rican localities. Biotropica 14: 141144.

Padial, J.M., Riva, I.D.L. 2009. Integrative taxonomy reveals cryptic amazonian species 
of pristimantis (anura). Zoological Journal of the Linnean Society, 155: 97-122.

Pearman, P.B. 1997. Correlates of amphibian diversity in an altered landscape of amazonian ecuador. Conservation Biology, 11: 1211-1225.

RCore Team 2015. R: Alanguage and environment for statistical computing. R Foundation for Statistical Computing, Vienna, Austria. URL https://www.R-project.org/.

Segalla, M.V.; Caramaschi, U.; Cruz, C.A.; Garcia, P.C.A.; Grant, T., Haddad, C.F.B.; Langone, J. 2014. Brazilian amphibians-List of species. Herpetologia Brasileira, 3(2): 37-48.

Silveira, M. 2005. A floresta aberta com bambu no sudoeste da Amazônia: padrões e processos em múltiplas escalas. Rio Branco: Editora da UFAC. p. 153.

Slowinski, J.B.; Crother, B.I.; Fauth, J.E. 1987. Diel differences in leaf-litter abundances of several species of reptiles and amphibians in an abandoned cacao grove in Costa Rica. Revista de Biologia Tropical, 35(2): 349-350.

Smith, M., Nelson. B.W. 2011. Fire favours expansion of bamboo dominated forest in the south-west Amazon. Journal of Tropical Ecology, 27: 59 - 64.

StatSoft, Inc. 2011. STATISTICA (data analysis software system), version 10. www.statsoft. com.

Toft, C.A. 1985. Resource partitioning in amphibians and reptiles. Copeia, 1-21.

Waldez, F.; Menin, M.; Rojas-Ahumada, D.P.; Lima, A.P. 2011. Population structure and reproductive pattern of pristimantis aff. Fenestratus (anura: Strabomantidae) in two non-flooded forests of central amazonia, brazil. South American Journal of Herpetology, 6: 119-126.

Recibido: 14 de marzo de 2018 Aceptado para publicación: 12 de julio de 2018 